DOI: https://doi.org/10.18509/AGB.2016.08

UDC:911.2:551.435.17.036(438)

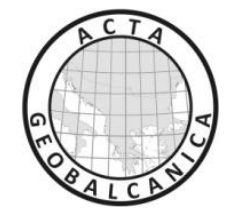

\title{
TUNNEL VALLEYS OF OLD GLACIAL LANDSYSTEMS IN POLAND
}

\author{
Małgorzata Frydrych $^{1}$ \& Zbigniew Rdzany ${ }^{1}$ \\ ${ }^{1}$ Department of Physical Geography, Faculty of Geographical Sciences, University of Łódź, \\ Poland \\ Corresponding author: zbigniew.rdzany@gmail.com
}

\begin{abstract}
Tunnel valleys are among the largest erosional structures in the Pleistocene cover of the Polish Lowland and other areas around the Baltic Sea. They have been fairly well recognised within the extent of the Weichselian (Vistulian) Glaciation. Research conducted in Northern Poland show that these forms may have originated as a result of either glacifluvial erosion, glacial erosion or both processes (glacialglacifluvial troughs).

In old glacial landscape areas, shaped during the Sanian (Elsterian) and Saalian Glaciations (Odra and Warta Glaciation), the outlines of tunnel valleys are now highly obliterated in the relief. No trough lakes have been preserved in these areas - such characteristic features in the extent of many tunnel valleys within the area of the LGM limit.

So far, deep erosional incisions in sediments of the Neogene, the Cretaceous and even the Jurassic, have been regarded as river palaeovalleys - particularly in the transitional area between the Polish Lowland and the uplands of Southern Poland. Even during field charting, related to the preparation of the Detailed Geological Map of Poland, these forms were frequently passed over in the legend. Only several investigators mentioned the possibility of the existence of old troughs, mentioning isolated cases thereof.

Analyses of drilling profiles, various archival geological and geophysical documentation and contemporary outcrops, allow for distinguishing over two hundred large structures of this type in the old glacial landscape belt - mostly buried. They were essential for subglacial drainage in the marginal part of the ice-sheet, by forming a several dozen kilometre wide parallel pattern. Some meltwater which eroded the substrate might have used old valley depressions, which were formed before the Pleistocene or in Eopleistocene. Petrographic composition of the gravelly debris was considerably modified under the influence of the local bedrock material.
\end{abstract}

Some tunnel valleys were filled still during the deglaciation, some were transformed by fluvial processes between the Eemian Interglacial and the Holocene, others are inversely indicated in the landscape in the form of eskers.

The identified forms here are on average smaller than the ones documented e.g. within the extent of the Weichselian Glaciation in Germany and in the North Sea. They reach from several to several dozen kilometres in length, from several to several dozen metres in depth and a considerable width - up to several kilometres.

Keywords: tunnel valley, old glacial landscape, glacifluvial sediments, Polish Lowland, Warta Glaciation. 


\section{INTRODUCTION}

Tunnel valleys belong among the largest erosional structures of the Pleistocene cover of the Polish Lowland and other areas around the Baltic Sea [1]. A number of other names are used to describe them: tunnel channel, subglacial tunnel, palaeovalley, overdeepened buried Quaternary valley, subglacial incision etc. [2]. They also occur on other continents, although the largest number of them were recognised within the extent of Pleistocene glaciations in the Northern hemisphere. They were also formed during pre-Pleistocene glaciations: Neoproterozoic, Ordovician (Hirnantian), and PermoCarboniferous. Recently, they have incurred a lot of interest, including the economic aspect, because the sandy-gravelly fills of these structures are frequently groundwater and hydrocarbon reservoirs. In Poland, they have been fairly well recognised within the extent of the Vistulian Glaciation (Weichselian). Research conducted in this area revealed that these forms may have been created as a result of glacifluvial erosion, glacial erosion or as an effect of both of these processes (glacial-glacifluvial tunnel valleys).

In the old glacial landscape areas in Poland, which were shaped during the Saanian (Elsterian, Middle Polish Glaciations), Odranian (Saalian I), and Wartanian (Saalian II) Glaciations, outlines of tunnel valleys have been obliterated in the landscape. In these areas, no trough lakes have been preserved whatsoever - so characteristic within the extent of tunnel valley occurrence in the area delimited by the Late Vistulian glacial maximum (LGM). Owing to poor legibility in the landscape, they usually have not been distinguished in geomorphological and geological maps. As a rule, deep erosional incisions of the Neogene, Cretaceous and even Jurassic sediments, have been interpreted as buried river valleys - especially in the Southern belt of the Polish Lowland and in the uplands of Southern Poland. Even during field studies, related to the development of the Detailed Geological Map of Poland, these forms were - apart from rare exceptions - omitted in its legend. The possibility of existence of old tunnel valleys was indicated by few researchers, who mentioned isolated examples thereof. They were distinguished e.g. along the line of steep-walled river valleys, as was the case for the Krzemionka valley [3].

The aim of this study was to develop a synthetic representation of the occurrence of documented or highly probable forms of the tunnel valley type in zones of various age of the old glacial landscape of the Polish Lowland and the uplands of Southern Poland, as well as to obtain data which support palaeogeographic reconstructions with regards to both the course of glacial events and later landscape transformations under different conditions of changing environment.

\section{DATA AND METHODS}

Due to important changes in the landscape in postglacial periods, after the Odranian and Wartanian glaciations and, in particular, after the Saanian Glaciation, the authors assumed three basic criteria for distinguishing tunnel valleys in the old glacial landscape areas:

1. The most credible indicator of the existence of tunnel valleys are subglacial eskers. As a result of numerous studies conducted so far, it has been found that the eskers in the area of the Polish Lowland were commonly formed in N-type channels (Nye channels). Frequently, these eskers occupy the trough form only partially - both lengthwise and 
widthwise. The Rzymsko esker - described in this volume [4] or the Rylsk esker [5] may be used as an example. While specifying the outline of the tunnel valley, sections of river valleys or depressions in the surface of plateaus in direct proximity of the eskers were also taken into account, if there were grounds to believe that they were parts of the tunnel valley.

2. The second assumption was based on the high probability of the occurrence of tunnel valleys underneath intermediate forms - of mixed esker-kame type and the so-called elongated kame ridges (compatible with the ice-sheet movement direction), if there were reasons to assume that they are "rooted forms", i.e. their floor lithofacies are found significantly lower (sometimes by several dozen metres) than the level of the ice-sheet substratum near the form.

3. The authors took into consideration direct and indirect results of research by different authors who interpreted the given forms as tunnel valleys, or whose collected data indicated the possibility of such an interpretation [6,7].

In the event of insufficient documentation of the existence and filling of the trough, the "underestimated" version as regards the size was assumed, e.g. restricted to the extent of the esker. One may assume that further progress of research will probably result in increasing the extent of many of the forms presented in Fig. 1. The resulting maps of tunnel valley occurrence are the first stage in the spatial recognition of the analysed forms, they show their course and major features of their outline.

Troughs related to eskers were distinguished on the basis of: the catalogue of Polish eskers [6], analysis of several hundred sheets of the Detailed Geological Map of Poland and their legends, as well as monographs and articles in the field of glacial geomorphology. The data was verified with topographic maps; geophysical materials were also taken into account. Sediments of selected tunnel valleys were studied by the authors also in outcrops within eskers and near them, but the studies were concentrated in sites in Central Poland. The data is constantly supplemented and processed geologically and cartographically in GIS software.

\section{MORPHOLOGICAL AND GEOLOGICAL FEATURES OF TUNNEL VALLEYS IN OLD GLACIAL LANDSCAPE BELT OF POLAND}

Analysis of works that have been published until now on tunnel valleys in areas to the South of the extent of the LGM indicates only a few examples of known forms of this type. No cartographical image of them has been presented so far - not only in relation to the entire area, but even to individual regions. Single examples of such forms, usually only partially reconstructed, can be found in just a few studies [3, 7, 8]. A critical review of the works, performed by the authors, allowed for formulating a reinterpretation of the genesis of various erosional forms, e.g. both currently functioning river valleys and palaeoforms - which were originally created as tunnel valleys. However, it was in particular the analysis of spatial distribution and internal structure of eskers and related landforms which led to distinguishing many such erosional forms. Deep erosional incisions were also taken into account, sometimes only as palaeoforms, which were not related to glacial forms on the surface. Such forms were documented among others by Szubert in the area of the Woźniki-Wieluń Upland [8]. Analysis of published works, drilling profiles, various archival geological and geophysical documentation and contemporary outcrops allows to isolate at this - it must 
be stressed - initial stage of research, about two hundred palaeostructures of the tunnel valley type in the old glacial landscape belt (Fig. 1). It must be pointed out that continuing the research into these forms may provide data on another group of forms, less legible, so far qualified into other categories.

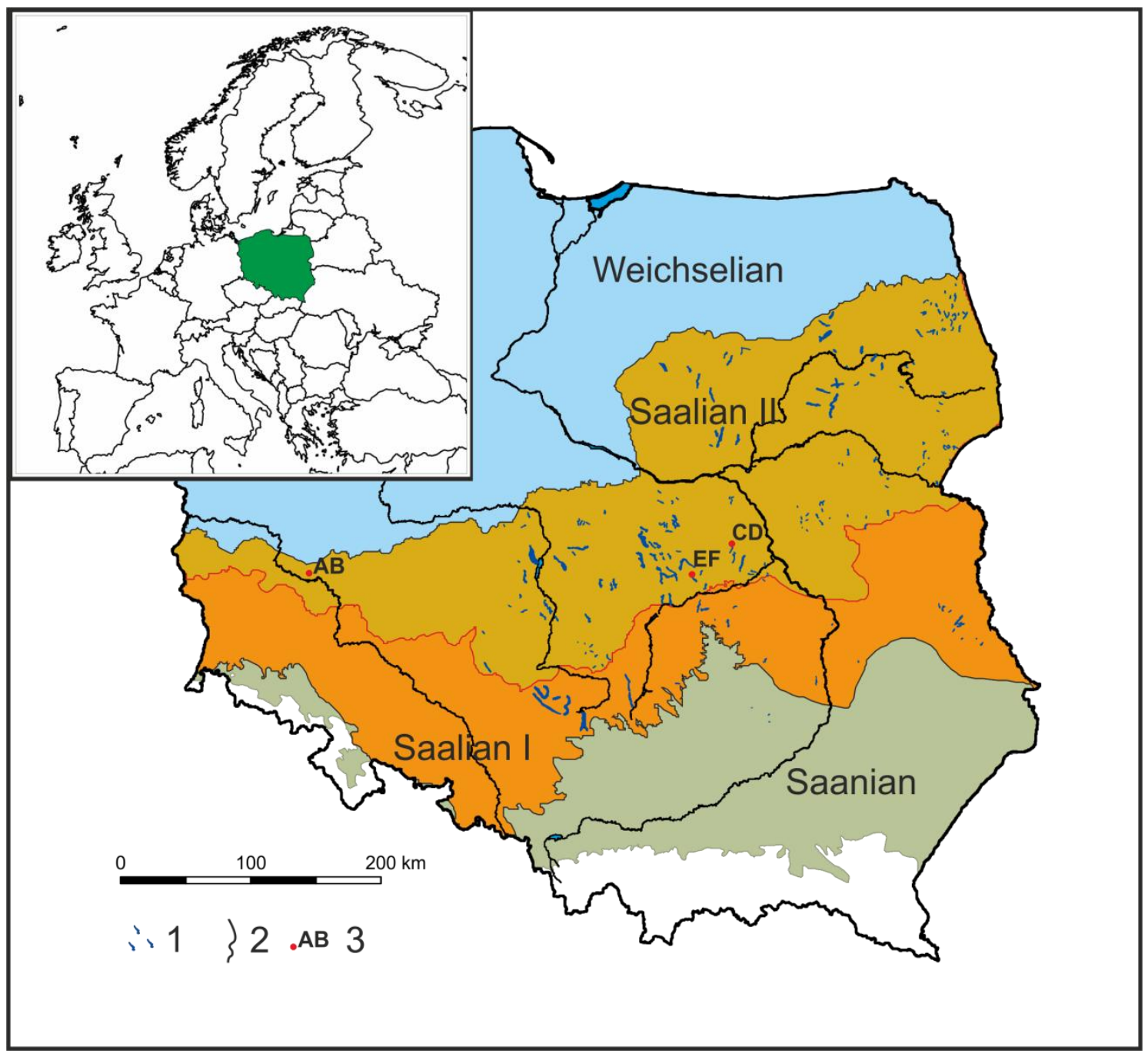

Fig. 1. Occurrence of tunnel valleys (1) in the old glacial landscape areas in Poland compared with glaciation extents [9] and major rivers (2), 3 - cross-sections through a tunnel valleys presented in the article. The map does not include tunnel valleys found within the extent of the last glaciation period (Vistulian, Weichselian).

The least legible traces of tunnel valleys are found within the extent of the South Polish Glaciations (Nidanian, Saanian), beyond the limits of the Odranian Glaciation. In these areas, only a few small forms can be distinguished. It cannot be ruled out that many erosional incisions related to river valleys, were used by waters of such tunnel systems, but at the same time, there is little evidence in favour of such reconstruction. Interpretation of the genesis of tunnel valleys within the extent of this glaciation is the most difficult, even due to the long denudation period after the glaciation, which may reach $0.5 \mathrm{Ma}$. Other reasons might include: lower activity of meltwater and moderately efficient glacial erosion caused by the cold thermal regime of the ice-sheet and 
prevalence of solid rocks in the ice-sheet substratum. Thus, the authors reconstructed here only several examples of forms.

A considerably larger number of tunnel valleys were identified in the landscape belt which was shaped during the Odranian Glaciation. Here, tunnel valleys were preserved from both the South Polish (Nidanian, Saanian) [10] and the Odranian glaciations.

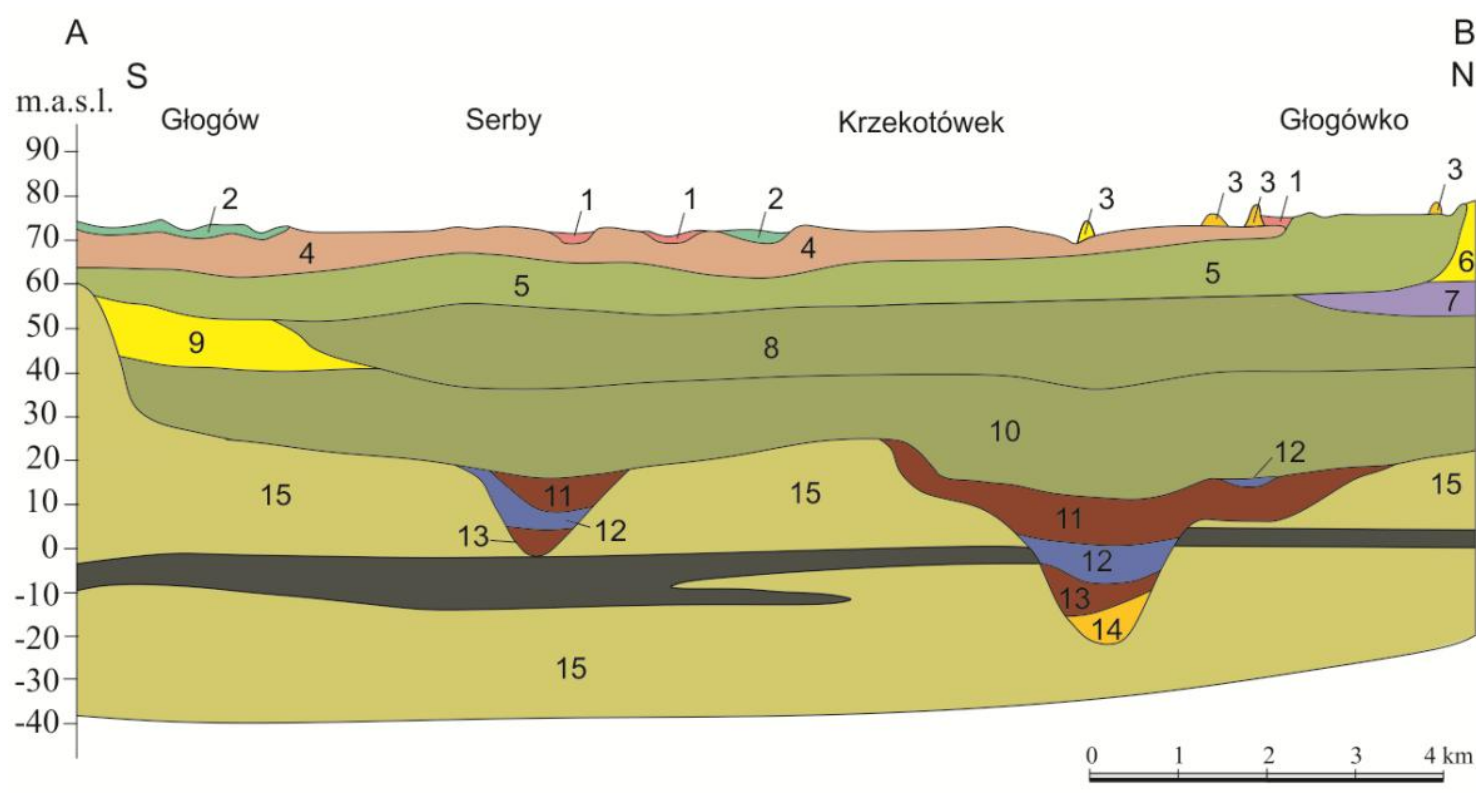

Fig. 2. Buried tunnel valleys from the South Polish Glaciation near Głogów (Silesian Lowland) based on a fragment of section by Michalska, modified and simplified [10]. Holocene: 1 - aggradate muds,

2 - clays and silts with an admixture of sands, 3 - aeolian sands, 4 - fluvial sands and gravels; Vistulian: 5 - fluvial sands gravels, 6 - fluvioglacial sands and gravels (of sandur type), Eemian Interglacial:

7 - lacustrine clays and silts, 8 - fluvial sands with organic remains; Odranian: 9 - fluvioglacial sands and gravels; Holsteinian: 10 - fluvial sands; South Polish Glaciations: 11 - till, 12 - glaciolacustrine sands and silts; 13 - till, 14 - fluvioglacial sands and gravels; Miocene: 15 - clays, silts, clayey silts, sands and lignite.

Eskers, which were formed in N-type tunnels, are fairly well preserved here and, in addition, it was proved that palaeovalleys with uneven thalweg line existed here (in the Woźniki-Wielun Upland), which were formed during this glaciation [8]. This view was supported with evidence from profile analysis of about five hundred drillings and the application of geostatistical methods. According to earlier views, the genesis of these palaeovalleys was related to fluvial erosion in the Early Pleistocene.

Within the extent of the Wartanian Glaciation, tunnel valleys occur most frequently (approx. 84\%), although their spatial distribution is fairly varied. It must be pointed out that the forms which exist here include not only those from the Wartanian, but also those from older glaciations (Fig. 3, 4). Tunnel valleys here were mostly filled with various sediments: glacifluvial, glaciolacustrine, fluvial etc. Some of them were filled with the subglacially transported material and are "inversely" marked in the landscape as esker forms, others were filled during deglaciation. Some tunnel valleys were transformed by fluvial processes in the period from the Eemian Interglacial to Holocene and are sometimes utilised by the contemporary river system. 


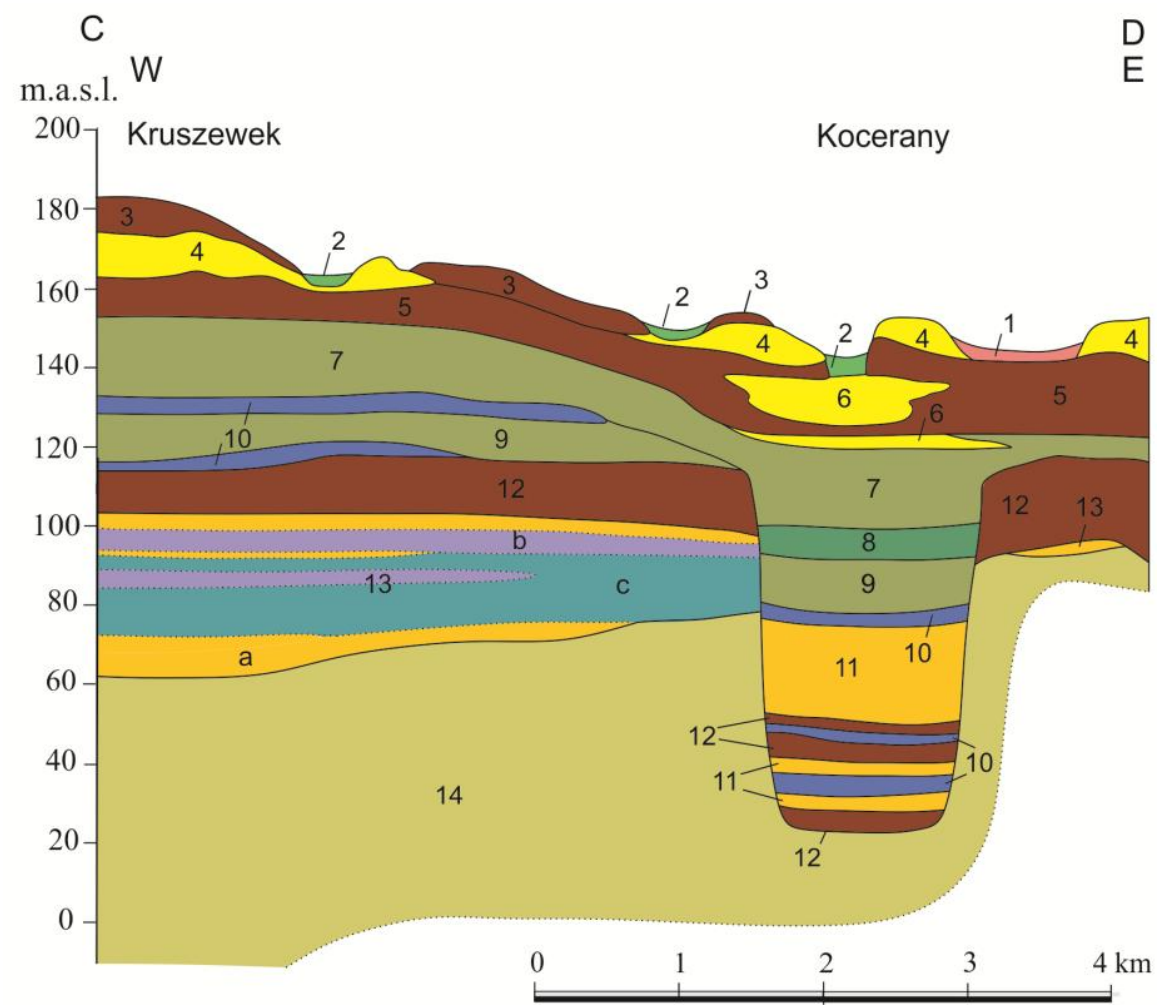

Fig. 3. A cross-section through a tunnel valley near Grójec (Mazovian Lowland) by Baraniecka, modified and simplified [11]: Holocene: 1 - aggradate muds, 2 - fluvial and slope sands;

Wartanian: 3 - till, 4 - fluvioglacial sands; Odranian: 5 - till, 6 - fluvioglacial sands;

Holsteinian: 7 - fluvial sands; Saanian: 8 - lacustrine silts, 9 - fluvial sands, 10 - glacilacustrine clays and silts, 11 - fluvioglacial sands, 12 - till; non-separated Quaternary: 13a - sands, $13 \mathrm{~b}$ silts, $13 \mathrm{c}$ - clays; Neogene: 14 - clays, silts and sands.

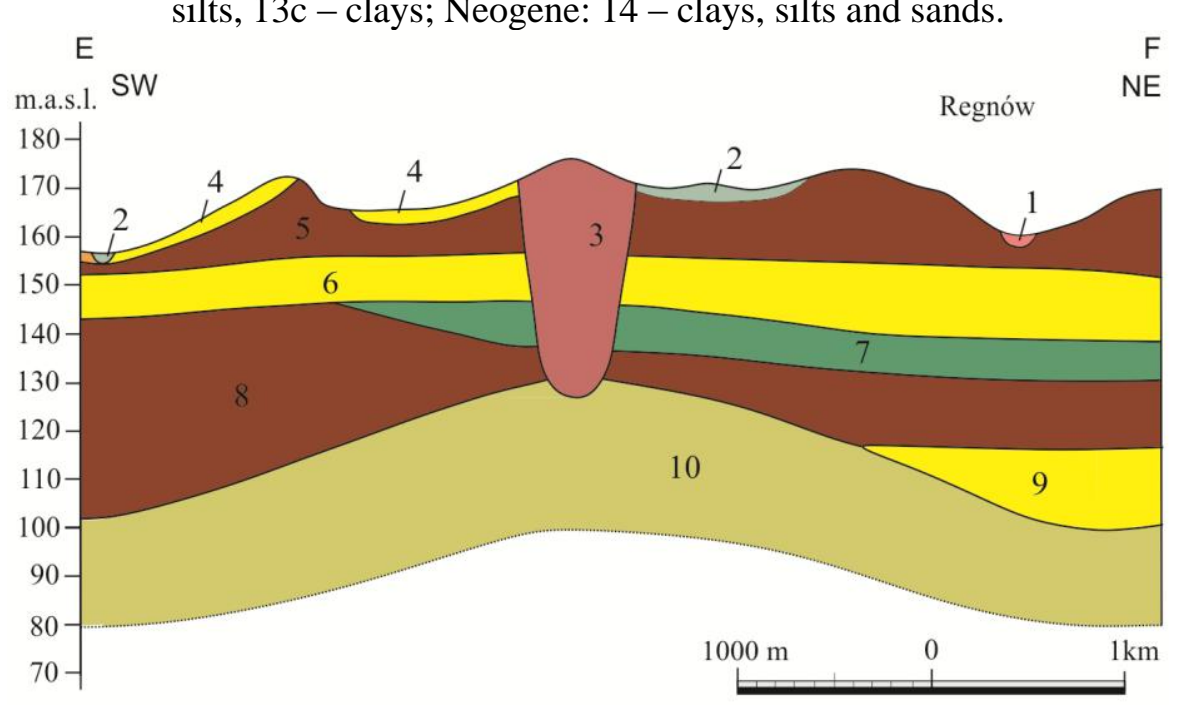

Fig. 4. A cross-section through the Rylsk esker by Włodek, modified and simplified [12]: 1 aggradate muds, silts and sands of valley bottoms and kettle holes, 2 - sands, silts and deluvial and colluvial silts and tills, Wartanian: 3 - sands and gravels of eskers and crevasse accumulation, 4 - glacial sands and gravels, 5 - boulder tills, 6 - fluvioglacial sands, 7 - fluvial and fluvioglacial, Odranian: 8 - boulder tills, 9 - fluvioglacial sands and gravels, Miocene: $10-$ sands, clays and silts with interbeddings of lignite. 
It must be noted that some meltwater which eroded the substrate might have used old valley depressions - which were formed before the Pleistocene or in periods that divided the subsequent glaciations, for which reason the original genesis of some erosional forms is difficult to determine. The petrographic composition of the gravelly sediment load which filled the troughs was to a large extent modified under the influence of the local bedrock material, both during the glaciation and in the period when interglacial fluvial processes operated. Because of this, it is sometimes difficult to distinguish fluvial gravels from glacifluvial ones. In tunnel valleys, glaciolacustrine sediments are also found, which might have been collected at stages of meltwater blockage, both during transgression and deglaciation. Overdeepenings of the thalweg line favoured the formation of lake reservoirs during interglacial periods.

Thanks to polygenesis, which often consisted in incorporating tunnel valleys into the drainage system at the end of the glaciation and during the subsequent interglacial period, these forms easily became elements of valley systems. This process is currently observed in Northern Poland, but it may be assumed that it occurred during every postglacial period. Due to this, the forms are usually marked as river valleys in geological and geomorphological maps. Some forms which were found in the area of the Warta Glaciation might have originated during earlier glaciations, to function in later interglacial periods as lake basins or river valleys (Fig. 3).

Tunnel valleys - related mainly to eskers (Fig. 1,4) - played a key role in the subglacial drainage in the marginal part of the ice-sheet, forming a parallel pattern from several to several dozen kilometres wide. Density of the system was varied, which is implied by a comparison of marginal extent belts of different glaciations.

\section{CONCLUSION}

Contrary to the quite common belief that, apart from a few exceptions, tunnel valleys do not occur in the old glacial landscape area, the authors think that these forms are relatively numerous there, particularly in the belt formed during the Wartanian Glaciation. Density of their occurrence, degree of preservation in the glacial landscape and in the fossilised state were dependent of the duration and intensity of denudation, glacial thermal regime, hydrogeological conditions and the morphology and lithology of the older bedrock.

The recognised forms here are on average smaller than those documented e.g. in the area of Northern Germany and the North Sea. They reach from several to several dozen kilometres in length and considerable width - up to several kilometres.

Two main regularities are indicated in the spatial distribution of tunnel valleys:

1. The first consists in different density of tunnel valley occurrence between individual belts. The older the landscape zone, the fewer tunnel valleys can be identified - the fewest within the extent of the South Polish Glaciations. In this area, all types of glacial forms are most poorly preserved in the scale of the entire area of Poland.

2. The second regularity consists in the increase of tunnel valley occurrence density from the West to the East in individual age belts of the glacial landscape. Significantly better conditions for the developments of the esker-type of tunnel valleys can be observed in the Eastern part of Poland, especially in the Podlasie region within the extent of the Wartanian Glaciation, where meltwater outflow may have been difficult. Eskers occur 
there in the neighbourhood of numerous kames. One might suppose that moderate glacial thermal regime dominated there.

The authors believe that further possibilities of precise recognition of spatial distribution and characteristics of tunnel valleys in the old glacial landscape area, exist in deep outcrops, analysis of deep drillings and studies of gravimetric anomalies, geoelectrical analyses and GIS methods.

\section{REFERENCES}

[1] van der Vegt P., Janszen A., Moscariello A. Tunnel valleys: current knowledge and future perspectives, Geological Society, London, Special Publication, Great Britain, vol. 368, pp. 75-97, 2013.

[2] Stumm D. Deep glacial erosion. Review with focus on tunnel valleys in northern Europe, Arbeitsbericht NAB 10-33, Wettingen, Switzerland, 2010.

[3] Balińska-Wuttke K. Geomorfologia obszaru między Skierniewicami a Rawą Mazowiecką, Prace Geograficzne IG PAN, vol. 23, pp. 1-93, 1960.

[4] Frydrych M. Sediments of high-energy meltwater flows: examples from Central Poland, Saalian Glaciation, Conference: GEOBALCANICA 2016, At Skopje, Republic of Macedonia (in this volume).

[5] Jaksa Z., Rdzany Z. Sedymentologiczny zapis dynamiki deglacjacji Wysoczyzny Rawskiej na przykładzie Wału Rylska (Sedimentological records of deglaciation dynamics of Rawa Upland exemplified by the structure of the Rylsk Ridge), Acta Universitatis Nicolai Copernici, Geografia XXXII - Nauki MatematycznoPrzyrodnicze, Toruń, vol. 109, pp. 169-181, 2002.

[6] Czernicka-Chodakowska D. Formy ozowe na obszarze Polski, Agencja Wydawnicza Vector, Warszawa, pp. 1-150, 1991.

[7] Huuse M., Lykke-Andersen H. Overdeepened Quaternary valleys in the eastern Danish North Sea: morphology and origin, Quaternary Science Reviews, vol. 19, pp. 1233-1253, 2000.

[8] Szubert M. Plejstoceńska morfogeneza Wyżyny Woźnicko-Wieluńskiej związana ze stadiałem maksymalnym zlodowacenia Odry w świetle geostatystycznej rekonstrukcji powierzchni podplejstoceńskiej, Prace Monograficzne nr 635, Wyd. Naukowe Uniwersytetu Pedagogicznego, Kraków, pp. 1-181, 2012.

[9] Marks L., Ber A., Gogołek W. (ed.). Mapa geologiczna Polski 1:500 000, Państwowy Instytut Geologiczny PIB, Warszawa, 2006.

[10] Michalska E. Szczegółowa mapa geologiczna Polski, arkusz Szlichtyngowa (614), Państwowy Instytut Geologiczny, 1995.

[11]Baraniecka M. D. Objaśnienia do Szczegółowej mapy geologicznej Polski 1:50 000, arkusz Grójec (596), pp. 1-116, 1980.

[12] Włodek M. Szczegółowa mapa geologiczna Polski, arkusz Rawa Mazowiecka (631), Państwowy Instytut Geologiczny PIB, 2009. 